\title{
The Effect of MMS Lubrication on Surface Roughness During Machining
}

\author{
A. KÁRI-HoRVÁTH ${ }^{1}$, T. PATAKI ${ }^{2}$, Z. SZAKÁL ${ }^{3}$ \\ Institute for Mechanical Engineering Technologies, Faculty of Mechanical Engineering, Szent István University \\ E-mail: kári-horváth.attila@gek.szie.hu¹; pataki.tamas@gek.szie.hu²; szakál.zoltán@gek.szie.hu
}

Abstract. I display this paper the chipping front metal of cutting allocated geometric, considering particular the friction. I catch the attention energy's balance sheet someday metal of cutting, open one new direction the manufacture technology. I display this new direction's metal of cutting condition. but built I delineate his paper final division this new policy searching programme, consumed trial instruments as well as the evaluation's mode.

\section{Introduction}

The development of elements is not equal in the machine - cutting tool - cooling lubricant - workpiece systems, but one of the elements always enforces the development of the other system elements which result in the collective system development collectively. The goal of the present-work is to illustrate the uneconomy and environment pollution of lubrication technologies used until now. The development is imperative in this field. The minimal quantity lubricant (MQL) is one of the development trends (courses) immediate with which results can be got. Its further global advantage is the complete paradigm-shift in the mechanical engineering technology sometime in the future.

\section{Cutting with geometrically determined cut}

Complicated stress and deformation states are present in the cutting zone, Fig.1 shows this.
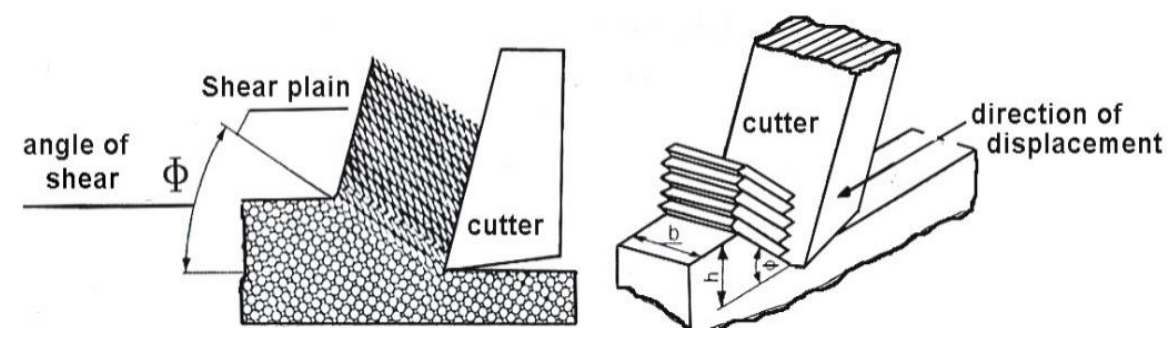

Figure 1. Process of cutting (the inside friction)

- As the cutter penetrates into the workpiece material it plastically deforms the material particles near the edge of the cutter. The particles slide on one another generally at one definite plane (shear plane) in the „h" thick layer. The chip-removal can be divided into three characteristic phases from a tribological point of view. These are: 
- Internal friction arises in the material machined as a result of the sliding of particles on one another along the shear plane. The stress in the material layer near the edge of the cutter will be higher and higher, it reaches a critical level that the material can't resist and the material ruptures. That material rupture is called unconditional rupture, as it happens in every case independently from the cutting conditions. Two new surfaces are formed during material rupture: the chipped surface and the inner surface of the chip. The rupture can extend to the shear zone at certain conditions but only after the completion unconditional rupture. This is called conditional rupture.

- The removed particle (chip) slides mainly on the tool-face and a lesser amount on the tool-back from the deformation zone while friction resistance and wear are formed. This is called solid (external) friction.

- Fusions and solid material particles are also formed at the cutting edge of the tool, some part of which leaves between the tool-back and the fress-machined surface, causing back-wear and surface damage.

\section{The presentation of the experimental circumstances}

Figure 2 demonstrates research program.

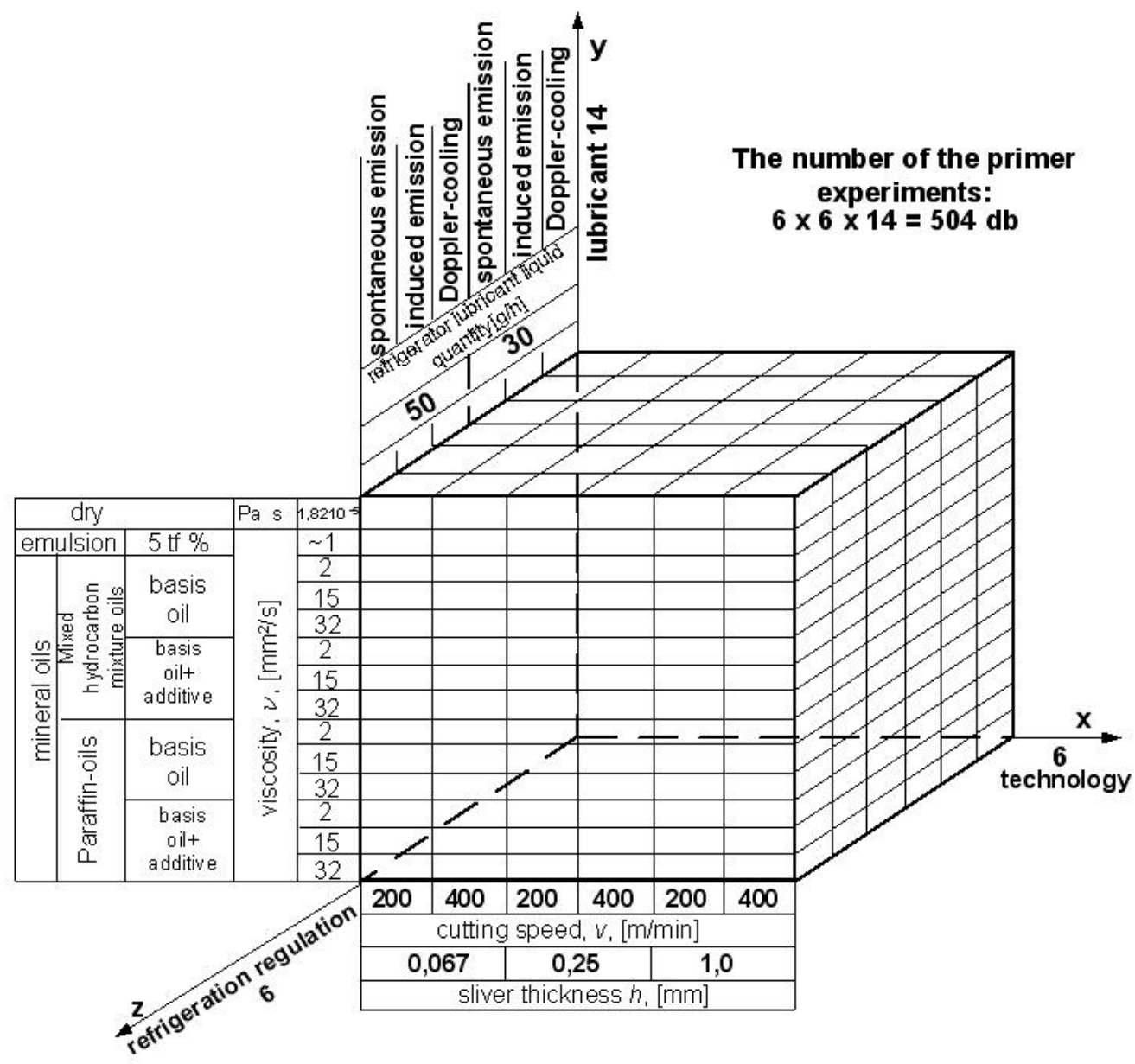

Figure 2. The experimental program 
Pilot data

Normal climate DIN50014 and IS0554-1970

Tool: HC/TiN, a DIN/ISO 513, CNMG 120408 PF 4015

Workpiece: 2CrMo4 (1.7225)

The machine-tool: C11A -single- spindle

System of minimal lubrication: Cobra 2000
Technological data

- step over: $f(h)=0,25 \mathrm{~mm}$

- step over: $f(h)=0,067 \mathrm{~mm}$

- step over: $f(h)=1 \mathrm{~mm}$

- step depth: $a(b)=1 \mathrm{~mm}$

- measured spindle speed: $n=1730 \mathrm{~min}^{-1}$

Table 1. Pilot data and the technological data

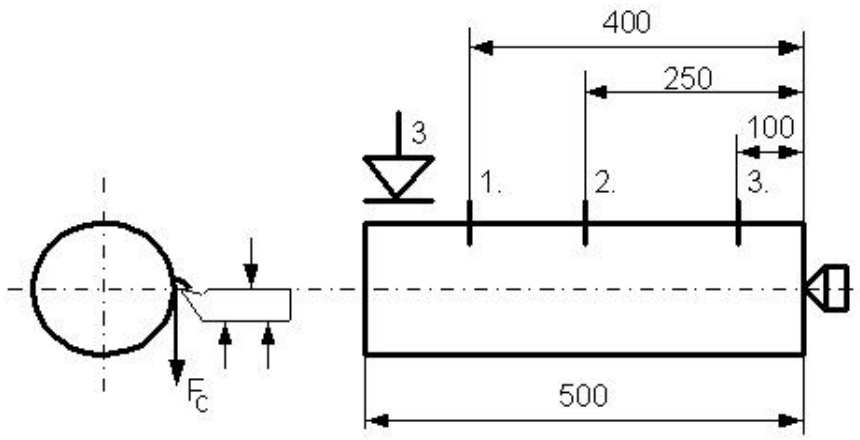

Figure 3. The measuring sets and places

\begin{abstract}
Measuring instruments
traditional micrometer (measuring range: 50 - 75mm and 75$100 \mathrm{~mm}$ )

traditional caliper $(1 / 20-150 \mathrm{~mm})$

metal microscope (Zeits Axi imager 1M, and Axiovision 4.7)

WA33 (TYP PRLTA13) scale (accuracy: 0,001g) for measuring of the insert mass

inductive odometer for measuring cutting force (type: TR102) revolution counter for measuring revolution (own construction) measuring-data collector (spider8 control)

IGA 300 infra thermometer

Mitutoyo SJ 201P diamond headed surface profilmeter.

instruments generating photon electrons: photo-emission with visible light, laser cooling (laser: $1 \mathrm{~mW}, \lambda=630-680 \mathrm{~nm}$ ): either the

Doppler-cooling or side-strip cooling
\end{abstract}

Table 2. Measuring instruments, measured data

\title{
Calculated data
}

$D_{a}[\mathrm{~mm}], \quad v_{c}[\mathrm{~m} / \mathrm{min}], \quad s[\mathrm{~m}], \quad V_{f}\left[\mathrm{~mm}^{3} / \mathrm{s}\right], \quad V B[\mathrm{~mm}], \quad P_{c}[\mathrm{~kW}]$

Table 3. Calculated data

We took into consideration the shaping period of the tool from the start to the end of the step and the average value was calculated by the mathematical function of the Excel 2003 program. We fixed the result received so in the table. We prepared the following functions based on these table data then $\mathrm{Ra}$ - Vf (the average surface roughness - quantity of detached sliver), VB - s (the measure of back abrasion - length of tool path), VB - Vf (the measure of back abrasion - quantity of detached sliver). We determined the stability of the diameters and the specific cutting force from measured cutting forces which are drawn in diagrams, as well. We examined the different effects in MQL lubrication circumstances of $50 \mathrm{~g} / \mathrm{h}$ and $30 \mathrm{~g} / \mathrm{h}$ of oil use. We examined the effect of the viscosity, the molecular structure and the dopes of the oils in manipulated and not manipulated molecular circumstances. 


\section{Roughness and size keeping}

I depicted the average surface roughness based on the measured data under the time unit detached in the function of a sliver quantity. I present the cases qualified by me as extreme in this chapter.

It is possible to characterize the change of the average surface roughness with a tendency of two kinds in the course of the experiments. The 3. figure shows that the average surface roughness improves by the applied refrigeration continuously. Onto the applied lubricant (that a model liquid) the molecule manipulation is with a good effect.

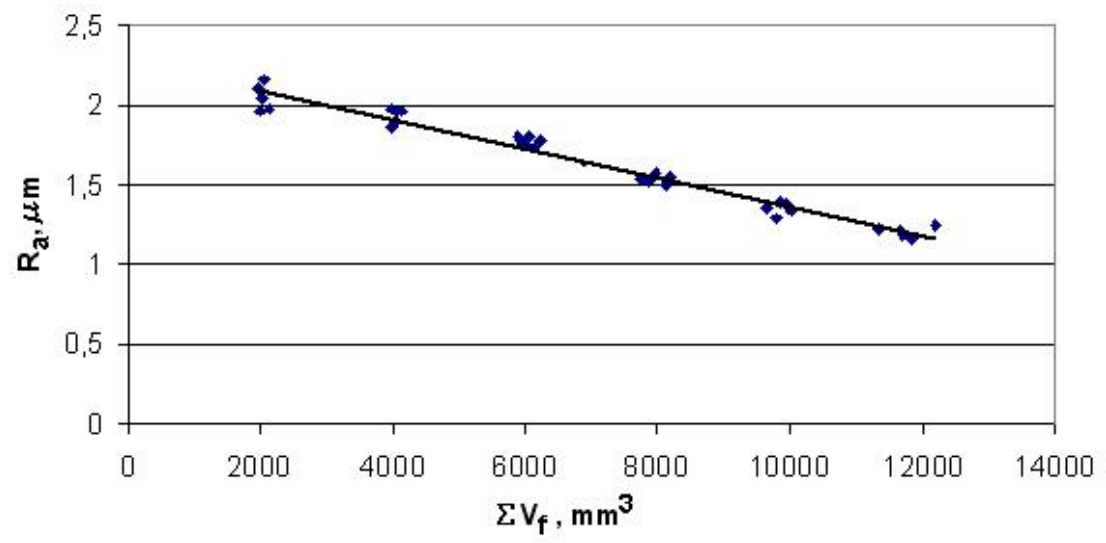

Figure 4. M2-2, Doppler-cooling $50 \mathrm{~g} / \mathrm{h}$

With a product which can be received on a market - on the same quantity and refrigeration manner the surface roughness improves likewise, after a point this is spoiling rapidly as the 4. figure shows it.

But here a much bigger dispersion can be observed. So can be related, that the roughness is repairable with the molecule manipulation, and an average suitable lubricant (Fig.3. data: Ra $=1,24$ ?) that compared with the emanated refrigeration $(\mathrm{Ra}=1,64 \mathrm{~m})$. with $5 \mathrm{v} \%$ volume percentages emulsion.

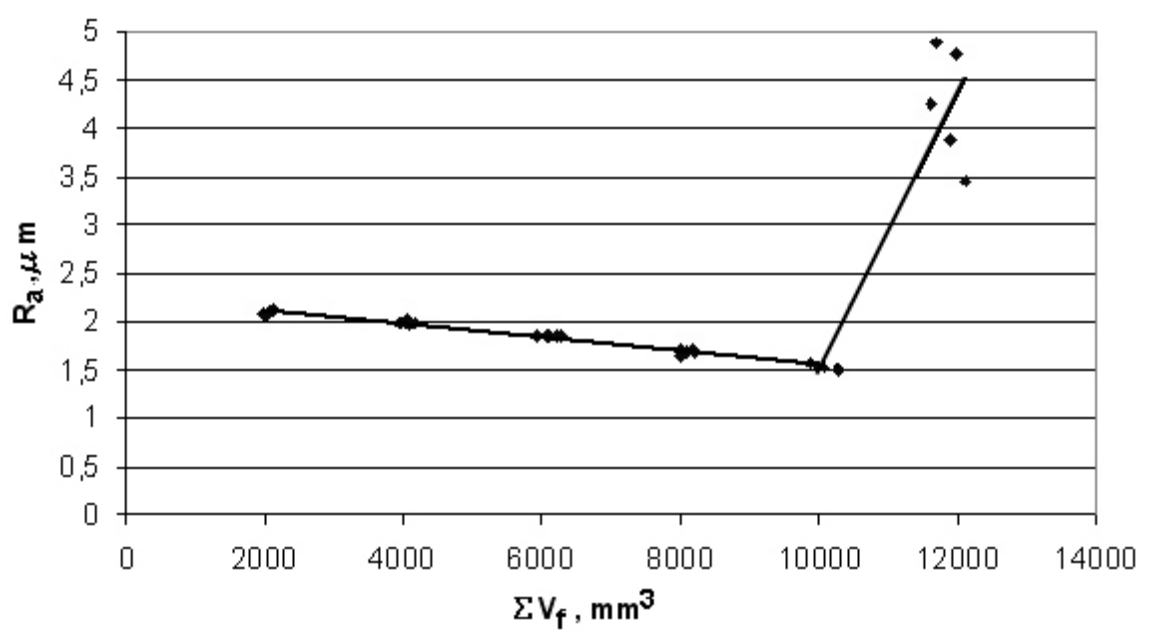

Figure 5. M1-32, Doppler-cooling $50 \mathrm{~g} / \mathrm{h}$ 
It gives the difference between the two diagrams, that by the measurement the knife reached the maximum value of the back abrasion before the 3 . measurement place. The mathematical context of the change of the surface roughness in all cases the successor:

$$
f(x)=\left\{\begin{array}{lll}
a_{1} x+b_{1} & \text { if } & A \leq 100 \\
a_{2} x+b_{2} & \text { if } & A \geq 100
\end{array}\right.
$$

where: „A" is the distance of the 3. measurement place (Fig.5.).

Based on the context this is visible from the diagram that presented ont he 5. figure, that the detached the average one makes it fall for roughness in the function of sliver volume, an improving one and a declining section of his exist.

This is emerges from a 5. figure, that can be reached in terms of the sliver detachment the best result by my done experiments with the C14 n-paraffin (M2-2) and with a molecule manipulation (induced emission).

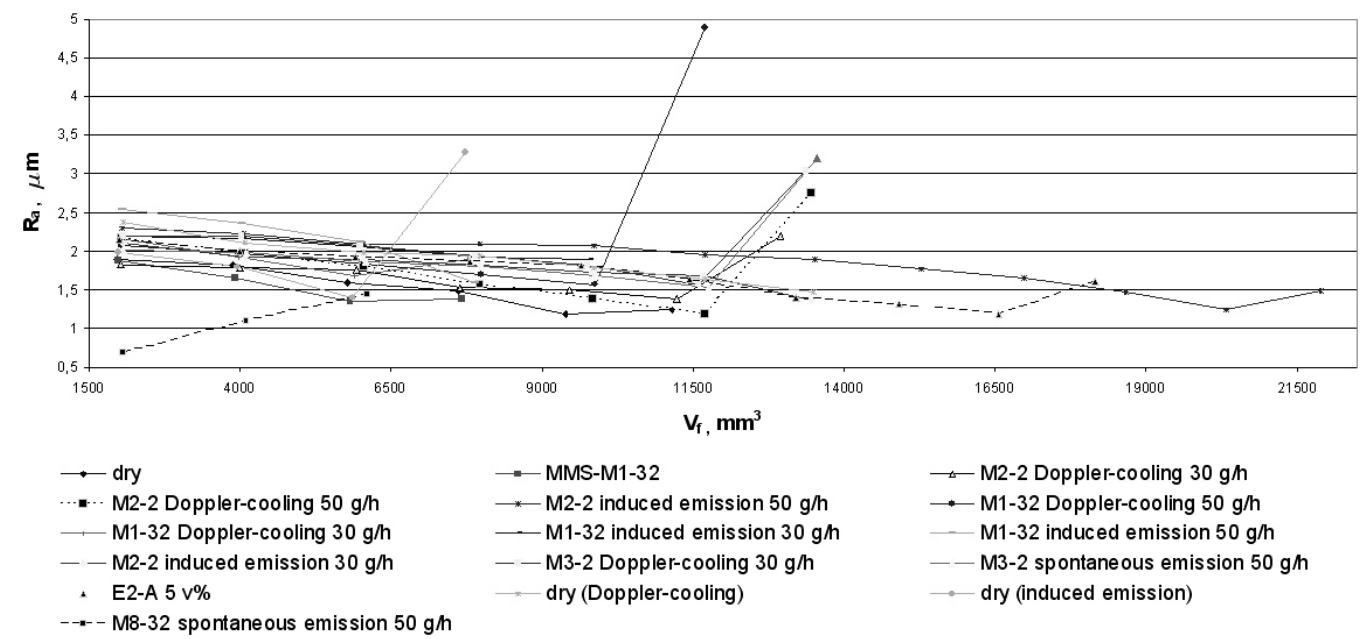

Figure 6. Aggregated diagram between the average surface roughness and the detached sliver volume

The development of the efficient cutting technology, by contacting to the continually intensifying requirements of size keeping and of the surface quality, progresses into the direction of the cutting velocity growing steadily and feeding.

The next assessment point concerned the size keeping of the products (workpieces). From measured diameters on the examination places I counted an average, I established the upper and lower differences compared to the average then. After that I defined it this from the standard, a what kind of tolerance grade the received values belong to how. For the definition of diameter stability (size keeping) I present an example in the followings.

\begin{tabular}{|c|c|c|c|}
\hline 1. $92,22_{-0,14}^{+0,13}$ & 2. $90,23_{-0,14}^{+0,13}$ & 3. $88,33_{-0,19}^{+0,1}$ & 4. $86,30_{-0,13}^{+0,14}$ \\
\hline 5. $84,44_{-0,14}^{+0,13}$ & 6. $82,59_{-0,09}^{+0,06}$ & \multicolumn{2}{|c|}{$\begin{array}{c}\text { The accuracy of the diameters } \\
\text { suits for the IT7 accuracy. }\end{array}$}
\end{tabular}

Table 6. Diameter stability 
Of course beyond the example mentioned already better, the IT4 accuracy class size keeping appeared too. This result the next experiments I received it:

- $\quad$ dry lubrication, Doppler- cooling

- $\quad$ M1-32 Doppler-cooling $50 \mathrm{~g} / \mathrm{h}$

- $\quad$ M1-32 induced emission $50 \mathrm{~g} / \mathrm{h}$

- $\quad$ M2-2 induced emission $50 \mathrm{~g} / \mathrm{h}$.

I received result in one case which can be assigned into an IT2 accuracy class:

- $\quad$ M1-32 Doppler-cooling $30 \mathrm{~g} / \mathrm{h}$.

Based on the analysis of the results can be declared, that the refrigeration manners applied by me are with influence onto the size keeping of the workpieces, the size keeping of the ready workpiece comes true so.

\section{References}

[1] W. J. Bartz 70 co-authors (2000) Kühlschmierstoffe und Zerspanung. Remingen-Malmsheim, expert-verlag.

[2] Á. Csurgay - K. Simonyi (1997) Az információtechnika fizikai alapjai - Elektronfizika. Mérnöktovábbképző Intézet, Budapest.

[3] A. Kári-Horváth (2009) A forgácsolásnál alkalmazott minimálkenés (MQL) hatásmechanizmusa és hatékonyságának növelése. Doktori értkezés, Gödöllő.

[4] M. Kronenberg (1954) Grundzüge der Zerspanungslehre, Springer-Verlag, Berlin.

[5] P. Lenard (1902) Über die lichtelektrische Wirkung. Ann. der Phys. 8 pp. 149-198.

[6] I. Valasek - I. Tóth (2003) Megmunkálástribológia. Tribotechnik Kft, Budapest.

[7] I. Valasek - A. Kári-Horváth (2007) Az üzemi emulziókezelési technológia felülvizsgálata és fejlesztési irányának meghatározása. Gépgyártás. 67 (5) pp. 18-25.

[8] I. Valasek - A. Pálffy - A. Kári-Horváth (2007) Minimálkenésú (MMS) forgácsolási jellemzők meghatározása. Gépgyártás 67 (2-3) pp. 47-56.

[9] G. Zwingmann (1976) Kühlschmierstoffe für die spanende Metallbearbeitung. Werkstatt und Betrieb. 10 (6) pp. 409-414. 